\title{
Theological Attitudes Toward the Scriptural Text: Lessons from the Qumran and Syriac Exegetical Traditions
}

Angela K. Harkins

Fairfield University, aharkins@fairfield.edu

\section{Peer Reviewed}

\section{Repository Citation}

Harkins, Angela K., "Theological Attitudes Toward the Scriptural Text: Lessons from the Qumran and Syriac Exegetical Traditions" (2006). Religious Studies Faculty Publications. 16.

http://digitalcommons.fairfield.edu/religiousstudies-facultypubs/16

\section{Published Citation}

Harkins, Angela K. "Theological Attitudes Toward the Scriptural Text: Lessons from the Qumran and Syriac Exegetical Traditions." Theological Studies 67.3 (2006): 498-516.

This Article is brought to you for free and open access by the Religious Studies Department at DigitalCommons@Fairfield. It has been accepted for inclusion in Religious Studies Faculty Publications by an authorized administrator of DigitalCommons@Fairfield. For more information, please contact digitalcommons@fairfield.edu. 


\title{
THEOLOGICAL ATTITUDES TOWARD THE SCRIPTURAL TEXT: LESSONS FROM THE QUMRAN AND SYRIAC EXEGETICAL TRADITIONS
}

\author{
ANGEla Kim HaRKINS
}

\begin{abstract}
The author examines how current textual-critical views and premodern attitudes toward the scriptural text offer today's theologians helpful perspectives on the Scriptures. The Qumran and Syriac exegetical traditions provide premodern examples of how interpretive communities of faith can read the Scriptures in a way that is both attentive to their literary form and richly theological.
\end{abstract}

$\mathrm{D}$ ISCONTENT OVER THE divide between Scripture and theology has recently drawn attention to interpretive strategies associated with the historical-critical method. ${ }^{1}$ If one surveys the scholarly literature on this topic, one can detect varying degrees of discontent with conventional historical-critical methods of biblical analysis, which, when used in isolation

Angela Kim Harkins holds a Ph.D. in Christianity and Judaism in Antiquity from the University of Notre Dame. Formerly assistant professor in the Department of Theology, Duquesne University, Pittsburgh, she has recently joined the Department of Religious Studies at Fairfield University, Connecticut. Her areas of special competence include the Dead Sea Scrolls, Old Testament/Hebrew Scriptures, and biblical interpretation. She has recently published "Observations on the Editorial Shaping of the So-called Community Hymns in $1 \mathrm{QH}^{\mathrm{a}}$ and $4 \mathrm{Q} 427$ $\left(4 \mathrm{QH}^{\mathrm{a}}\right)$," Dead Sea Discoveries (2005), and is researching apocalyptic images in the Qumran Hodayot for a future publication.

${ }^{1}$ Many scholars have commented on the limitations of scientific approaches to Scripture and theological studies, including: Brevard S. Childs, Biblical Theology in Crisis (Philadelphia: Westminster, 1970); James Smart, The Strange Silence of the Bible in the Church: A Study in Hermeneutics (Philadelphia: Westminster, 1970); Hans W. Frei, The Eclipse of Biblical Narrative: A Study in Eighteenth and Nineteenth Century Hermeneutics (New Haven: Yale University, 1974); David C. Steinmetz, "The Superiority of Pre-Critical Exegesis," Theology Today 37 (1980) 27-38; Joseph Ratzinger, "Biblical Interpretation in Crisis: On the Question of the Foundations and Approaches of Exegesis Today," This World 22 (Summer 1989) (quotations taken from the reprinted version in Richard John Neuhaus, gen. ed., Biblical Interpretation in Crisis: The Ratzinger Conference on Bible and Church [Grand Rapids, Mich.: Eerdmans, 1989] 1-23); Lewis Ayres and Stephen E. Fowl, "(Mis)reading the Face of God: The Interpretation of the Bible in the Church," Theological Studies 60 (1999) 513-28; Joel B. Green, "Scripture and Theology: Failed Experiments, Fresh Perspectives," Interpretation 56 (2002) 5-20; Craig Bartholomew, C. Stephen Evans, Mary Healy, Murray Rae, ed., "Behind" the Text: History and Biblical Interpretation (Grand Rapids: Zondervan, 2003). 
from other interpretive strategies, seem unable to produce a theologically fruitful study of Scripture. Given this divide, scholars of the previous century have suggested that a retrieval of premodern interpretive strategies may offer a way of bridging biblical studies and theological inquiry. ${ }^{2}$ In a way similar to the situation of the ancient interpreter, the exegete today has at his or her disposal various interpretive strategies from the secular world. ${ }^{3}$

This article will examine, from the perspective of modern textual criticism, premodern attitudes of the Qumran and Syriac exegetical traditions to better understand how modern criticism can yield a more nuanced reading of the Scriptures that is both consistent with premodern understanding and more open to theological inquiry. Eugene Ulrich has already made the point that, prior to their canonization, the authority of sacred texts did not rely on their specific textual form. ${ }^{4}$ In other words, texts that would later

${ }^{2}$ See Steinmetz, "The Superiority of Pre-Critical Exegesis"; Ayres and Fowl, "(Mis)reading the Face of God"; Brian Daley, "Is Patristic Exegesis Still Usable? Reflections on the Early Christian Interpretation of the Psalms," Communio 29 (2002) 185-216. Also, Marie Anne Mayeski, "Quaestio Disputata: Catholic Theology and the History of Exegesis," Theological Studies 62 (2001) 140-53, responds to Michael Cahill, "The History of Exegesis and Our Theological Future," Theological Studies 61 (2000) 332-47, surveying various ressourcement theologians (e.g. Henri de Lubac, Jean Daniélou, Louis Bouyer) and identifying the allegorical and typological approaches of the church fathers as offering a way for theology to be historical without resorting to historical-critical scholarship. Mayeski presents the allegorical approach used by patristic theologians as an example of how close attention to the text and to history can generate a theologically rich understanding. See also Luke Timothy Johnson and William Kurz, S.J.. The Future of Catholic Biblical Scholarship. A Constructive Conversation (Grand Rapids: Eerdmans, 2002); Michael C. McCarthy, "An Ecclesiology of Groaning: Augustine, The Psalms, and the Making of Church," Theological Studies 66 (2005) 23-48.

${ }^{3}$ Like others, I am not suggesting a thorough rejection of historical criticism in favor of a premodern interpretive approach. As de Lubac writes, "we would be just as mistaken-and, here again, we are overstating the case, without suggesting that the opinion can actually be supported-if we admired the ancient constructs so much that we longed to make them our permanent dwelling; or if we canonized such doctrines so as to become unconscious of their weak or outdated aspects: or if we believed that fidelity to an author meant that we had to copy him or imitate him slavishly.... There is no point in wondering what one of the ancients would do if he were alive today, in totally different conditions, and discovered all sorts of curious things unknown in his own day, enjoyed a more advanced stage of scientific development, could use the new tools of scholarship, was enlightened by an experience of the world whose very orientation could not have been foreseen by him. There is simply no answer to such questions" (Scripture in the Tradition, trans. Luke O'Neill, intro. Peter Casarella [New York: Herder \& Herder, 1968] 2-3).

${ }^{4}$ Eugene C. Ulrich, "Qumran and the Canon of the Old Testament," The Biblical Canons, ed. J.-M. Auwers and H. J. de Jonge (Leuven: Leuven University, 2003) $57-80$. 
become known as "biblical" were authoritative despite their pluriformity. The authority of these scriptural texts likely stemmed from the faith community's recognition of the power of sacred writings to signify meaning about the divine. Premodern interpreters, from both Qumran and the Syriac exegetical tradition, understood the scriptural text to be open to a revelatory discourse. It is clear that for these two ancient interpretive communities, the process of interpretation was an inspired activity, richly theological, and imaginative. The ceremonial and ritualized reading and reinterpretation of scriptural texts within communal contexts were activities that allowed for this textual pluriformity and perhaps even demanded it. A more nuanced notion of the biblical text itself may help contemporary scholars of the Bible and theology recover a conceptualization of the Scriptures that is both more consistent with the perspective of ancient and late antique exegetes and also more open to theological inquiry.

\section{PRELIMINARY REMARKS ON THE MODERN SCIENTIFIC STUDY OF THE BIBLE}

While much can be said about the relationship between scientific approaches to the Bible and theological studies, I am most interested in the attitudes toward or assumptions about the biblical text in these scientific methods. In 1859 Benjamin Jowett, Regius Professor of Greek at the University of Oxford, wrote: "Scripture has one meaning - the meaning which it had in the mind of the Prophet or Evangelist who first uttered or wrote, to the hearers or readers who first received it." 5 According to this perspective, Scripture's earliest recoverable literary form is often thought to be the most certain means of accessing its authentic meaning. More than a century later, David Steinmetz argued against the singularity of the interpretation presumed by historical criticism in favor of the superiority of precritical exegesis and the multiple interpretations that its methodological stance allows. ${ }^{6}$ Jowett's statement, "Scripture has one meaning," reflects historical criticism's single objective of recovering the intent of the human author that lies behind the biblical text. With the rise of postmodernism, the objectivity of the scientific methods of the previous centuries has been challenged and critiqued, with textual determinacy falling to indeterminacy. ${ }^{7}$ There is an irony here: modern biblical studies concentrates

${ }^{5}$ Benjamin Jowett, “On the Interpretation of Scripture," Essays and Reviews, 7th ed. (London: Longman, Green, Longman and Roberts, 1861) 378.

${ }^{6}$ Steinmetz, "The Superiority of Pre-Critical Exegesis."

${ }^{7}$ See the discussion by Terence J. Keegan, "Biblical Criticism and the Challenge of Postmodernism," Biblical Interpretation 3 (1995) 1-14; also Craig G. Bartholomew, introduction to "Behind" the Text 8-10. 
Scripture's authority in the earliest text; postmodern studies finds it difficult to locate Scripture's authority at all; both find themselves struggling to articulate what is distinctive and valuable about their respective methods.

One might say that the type of discipline proposed by biblical scholars of the modern period is thoroughly Protestant in its endeavor to strip away the dogmatic (ecclesial) accretions of the Bible's theology. After all, few would argue with the statement that much of the formative development of contemporary biblical studies happened within Protestant circles. Historical criticism's objective of describing from a historical perspective the original theological concerns of the biblical text and the method's privileging of the literal text resembles a Protestant stance toward Scripture vis-à-vis tradition. Indeed, the prominent Jewish scholar James Kugel remarks that the sifting out of what may be demonstrated as early or authentic from what are secondary accretions and then prioritizing them is a process that itself resembles the early Protestant distinction between "the divine Word of Scripture" and the secondary "merely human words of Church interpreters." ${ }^{8}$ Kugel goes on to cite a description of the goal of historical criticism that was articulated by C. A. Briggs, professor of Bible at Union Theological Seminary in New York at the turn of the previous century. In his introduction to the Old Testament, Briggs made the following rather telling statement: "The valleys of biblical truth have been filled up with the débris of human dogmas, ecclesiastical institutions, liturgical formulas, priestly ceremonies, and casuistic practices. Historical criticism is digging through this mass of rubbish. Historical criticism is searching for the rock-bed of the Divine Word, in order to recover the real Bible. Historical criticism is sifting all this rubbish. It will gather out every precious stone. Nothing will escape its keen eye." ${ }^{9}$ While neither an exhaustive nor exclusive way of conceptualizing the modern period of biblical studies, Kugel's point that the historical-critical enterprise as primarily an endeavor to strip away secondary layers from a pristine core did not go unnoticed. ${ }^{10}$

${ }^{8}$ James L. Kugel, "The Bible in the University," The Hebrew Bible and Its Interpreters, ed. William Henry Propp, Baruch Halpern, and David Noel Freedman (Winona Lake, Ind.: Eisenbrauns, 1990) 161. Kugel faults the proponents of biblical theology for dismissing the value of ancient interpretations, both Christian and Jewish.

${ }^{9}$ C. A. Briggs, General Introduction to the Study of Holy Scripture (New York: Scribners, 1901) 531; also in Kugel, "The Bible in the University" 155-56.

${ }^{10}$ The efforts to renew the theological enterprise of scripture studies described by Childs, Steinmetz, and Green (see n. 1 above) could be described as a move toward embracing theological traditions within biblical scholarship. 
Briggs's conceptualization of the goal of historical criticism from the turn of the 20th century reflects an understanding of biblical studies that some might characterize as an antiquated presentation of the discipline. While Briggs's remarks may seem like a caricature to our ears today, its premise that the goal of the historical-critical method is to strip away what is secondary from what is the primary "original" text is a premise that has cast a long shadow over the discipline. His particular articulation of historical criticism highlights the problematic nature of the discipline for theological inquiry. Some Jewish scholars-James Kugel and Michael Fishbane, for example-have demonstrated in their literary studies that the scholarly distinction between the scriptural text and its interpretation is an artificial one that does not reflect how the Scriptures were experienced by actual ancient and medieval communities of faith. Scholars interested in the history of interpretation have shown how the use of literary and historical methods indicate that previously held conceptions of a text's historical development (e.g., scholarly views from the turn of the 20th century) were more theoretical than actual. Scholars have also illustrated how deeply the interpretive activity of the scribes, tradents, and redactors is embedded within the text to produce what is in effect its final form, the one we have today. ${ }^{11}$ The divide between Scripture and its interpretation is an artificial one that, in fact, misrepresents how the Scriptures were encountered by actual communities of faith in history. When the sacred text becomes an object of study in the way that Briggs proposed, the Scriptures become

${ }^{11}$ See the classic studies by Michael A. Fishbane, "Revelation and Tradition: Aspects of Inner-Biblical Exegesis," Journal of Biblical Literature 99 (1980) 343-61; Biblical Interpretation in Ancient Israel (Oxford: Clarendon, 1985); "Use, Authority, and Interpretation of Mikra at Qumran," in Mikra: Text, Translation, Reading, and Interpretation of the Hebrew Bible in Ancient Judaism and Early Christianity, ed. Martin Jan Mulder (Philadelphia: Fortress, 1988) 351-54; "Inner-Biblical Exegesis," Hebrew Bible/Old Testament: The History of Its Interpretation, vol. 1: From the Beginnings to the Middle Ages (Until 1300); part 1: Antiquity, ed. Magne Sæb $\varnothing$ (Göttingen: Vandenhoeck \& Ruprecht, 1996) 33-48. See also James L. Kugel, "Early Interpretation: The Common Background of Late Forms of Biblical Exegesis," Early Biblical Interpretation, ed. James L. Kugel and Rowan Greer (Philadelphia: Westminster, 1986) 9-106; Kugel, In Potiphar's House: The Interpretive Life of Biblical Texts (New York: HarperCollins, 1990); Kugel, Traditions of the Bible: A Guide to the Bible As It Was at the Start of the Common Era (Cambridge: Harvard University, 1998). See also, Brevard S. Childs, "Psalms, Titles, and Midrashic Exegesis," Journal of Semitic Studies 16 (1971) 137-50; Daniel Patte, Early Jewish Hermeneutic in Palestine (Missoula: Scholars, 1975); Geza Vermes, "Bible and Midrash: Early Old Testament Exegesis," Cambridge History of the Bible, vol. 1, From the Beginnings to Jerome, ed. P. R. Ackroyd and C. F. Evans (New York: Cambridge University, 1970) 199-231; Jacob Weingreen, "Rabbinic-Type Glosses in the Old Testament," Journal of Semitic Studies 2 (1957) 149-62. 
separated from the life of the community of believers ${ }^{12}$ and subsequently removed from theological inquiry. ${ }^{13}$ It is perhaps not surprising that the recent study by Luke Johnson and William Kurz critiques the historicalcritical method and urges a return to premodern strategies of interpretation that resemble the "four assumptions" of premodern interpreters cited by Kugel in his 1998 study on biblical interpretation. ${ }^{14}$

The 1993 Pontifical Biblical Commission's document, The Interpretation of the Bible in the Church, continues to be a much discussed document that surveys various interpretive methods, many of which fall under the category of historical criticism. ${ }^{15}$ The document describes historical-critical

${ }^{12}$ The Second Vatican Council's Dogmatic Constitution on Divine Revelation (hereafter $D V$ ) attempted to bridge this gap by emphasizing the radical dependency between Scripture and tradition, the Old and the New Testaments, and the human and divine, thereby giving a fuller expression to statements previously articulated by the Church. This mysterious mingling of the human and divine qualities of Sacred Scripture is discussed in $D V$ no. 12; Scripture's relationship with tradition is also described as "flowing from the same divine well-spring, both of them merge, in a sense, and move toward the same goal" ( $D V$ no. 9) which may be seen as a reaffirmation of the Church's teachings from the time of the Council of Trent. The distinction between Scripture and its traditional interpretation was not so hard and fast prior to the 16th century. The quotations from $D V$ are taken from Austin Flannery, ed., Vatican Council II: The Basic Sixteen Documents: Constitutions, Decrees, Declarations (Northport: N.Y.: Costello, 1996).

${ }^{13}$ Another way to describe the divide between theological inquiry and biblical studies is to trace the gap between Scripture and the community of faith that was broadened by the neo-Scholasticism that dominated Roman Catholic theology from the time of Pope Leo XIII's Eterni Patris in 1879. Characteristic of this neo-Scholasticism was the objectification of Scripture. As William Dickens put it in his treatment of the movement from the classic period to the modern: The Bible was seen "less as a guide to life and thought (with changing applications and therefore changing meanings) and more as an object of study (with a univocal meaning best discerned by experts)" (W. T. Dickens, Hans Urs von Balthasar's Theological Aesthetics: A Model for Post-Critical Biblical Interpretation [Notre Dame: University of Notre Dame, 2003] 8).

${ }^{14}$ Johnson and Kurz identify the following premises of premodern interpretation: (1) Old and New Testaments form a unity grounded in the singleness of divine authorship; (2) Scripture speaks harmoniously; (3) the Bible, as the word of God, is authoritative; (4) Scripture speaks in many ways and at many levels; (5) hermeneutics of generosity or charity (The Future of Catholic Biblical Scholarship 47-60). Compare this list with the "four assumptions" of premodern interpreters identified by Kugel: (1) "the Bible is a fundamentally cryptic document" in need of interpretation; (2) Scripture is "a fundamentally relevant text" of moral value; (3) "Scripture is perfect and perfectly harmonious"; (4) "Scripture is somehow divinely sanctioned, of divine provenance, or divinely inspired" (Traditions of the Bible, 14-19; emphasis original).

${ }^{15} \mathrm{http}: / /$ catholic-resources.org/ChurchDocs/PBC_Interp-FullText.htm. Studies 
exegesis as having, "adopted, more or less overtly, the thesis of the one single meaning. All the effort of historical-critical exegesis goes into defining 'the' precise sense of this or that biblical text seen within the circumstances in which it was produced." In general, the document evaluates positively the results of these methods in contrast to the negative assessment given to fundamentalist and allegorical readings. The PBC document recommends historical-critical method as the proper way to engage the human quality of the biblical text, while acknowledging the limitations of the method in a nuanced way. ${ }^{16}$

Several scholars have suggested that the secular interpretive methods associated with historical criticism may have some role in theological inquiry: however, it is unclear what that role might be. My position is that the application of historical methods is a valuable and worthy endeavor because they enable scholars to glimpse how the Scriptures were encountered by actual communities of faith from antiquity. In a recent study, Michael McCarthy demonstrates how the dynamic oral interpretations of Scripture known to have occurred in the ecclesial settings in late antiquity demand that scholars adopt a more nuanced understanding of "exegesis" todayone that is vibrant and embodied. He writes:

I examine here how the revelatory word operates in the Church by highlighting an aspect of patristic exegesis that goes largely unexplored by historical theologians: its social and cultural function. At least since the rise of the historical-critical method. biblical exegesis has remained an overwhelmingly silent affair and has enjoyed a certain independence from an ecclesial setting. "Texts" (as the Bible is so frequently conceived) lie open for scientific examination, inquiry, and comment, but

on this text are numerous. See, e.g.. Joseph A. Fitzmyer, The Biblical Commission's Document "The Interpretation of the Bible in the Church": Text and Commentary (Rome: Pontifical Biblical Institute, 1995): I. Howard Marshall, "Review: 'The Interpretation of the Bible in the Church." 'Scottish Bulletin of Evangelical Theology 13 (1995) 72-75; Ayres and Fowl. "(Mis)Reading the Face of God" 513-28: Johnson and Kurz, Future of Catholic Biblical Scholarship; Daley, "Is Patristic Exegesis Still Usable?" 185-216: and Peter S. Williamson, "The Place of History in Catholic Exegesis: An Examination of the Pontifical Biblical Commission's The Interpretation of the Bible in the Church." in "Behind" the Text 196-226.

16 The PBC document highly values historical-critical approaches to Scripture while acknowledging their limitations. See Williamson, "The Place of History in Catholic Exegesis" 196-226. Ayres and Fowl, however, challenge the positive valuation of the historical-critical method. arguing that its indispensability is not warranted. On this point see their "(Mis)reading the Face of God," which critiques the recommendations offered by the PBC's Interpretation of the Bible in the Church. They reject the document's equating a text's divine meaning with the intended meaning of the human author (520-21) and also cite the failure of historical-critical readings to build up the community and foster contemplation of God, which are better cultivated by interpretive strategies that allow a plurality of readings. 
in the scholarly mode such researches are individually pursued and physically mute. For the ancient Church, on the other hand, the Bible provided foremost and predominantly a public, oral, and auditory encounter. ${ }^{17}$

One might say that these embodied exegeses of the Scriptures allowed premodern interpreters to conceptualize the Scriptures in a way that was open to transcendent meaning while taking seriously its wording or textuality - thus paying careful attention to the littera, while avoiding the dangers of literalism. According to McCarthy, embodied exegesis, its oral modality and public performance, is efficacious because "it generates the ecclesia at a distinct historical moment." 18 The interpretation of the Scriptures within a faith community can take on a peculiar efficacy and become capable of creating and forming community in a profound way.

What I would like to note in this essay is that the performative and dynamic aspects of interpretation allow for and even demand a textual pluriformity. Both ancient and premodern communities of faith often presume textual polyvalence and an awareness of the Scriptures' peculiar efficacy. ${ }^{19}$ With information from Qumran, biblical scholars can see that historical inquiry into the nature of the scriptural text in antiquity yields not singularity but pluriformity. In the following sections, I will look at how the Qumran and Syriac exegetical traditions are examples of this premodern recognition of Scripture's polyvalency and plurality.

\section{LESSONS FROM THE DEAD SEA SCROLLS}

Unlike the situation of the premodern period, careful attention to the littera by biblical exegetes today does not necessarily yield a fruitful theological exegesis. Nevertheless, a historical scientific approach may be able to assist scholars who are interested in theological inquiry by bringing to light a different understanding of Scripture, one that has greater continuity with a premodern understanding of the text. Here I turn to the specific discipline of textual criticism which has changed and developed through the years. ${ }^{20}$ Textual criticism of the Dead Sea Scrolls, shows that the scrip-

${ }^{17}$ McCarthy, "An Ecclesiology of Groaning" 24-25.

${ }^{18}$ Ibid. 25.

${ }^{19}$ Albert van der Heide, "Midrash and Exegesis," in The Book of Genesis in Jewish and Oriental Christian Interpretation, ed. Judith Frishman and Lucas Van Rompay (Louvain: Peeters, 1997) 43-56, draws a distinction between the midrash of the rabbis and modern exegesis. The former allowed for a polyvalence of the text that the latter does not allow. Van der Heide suggests that rabbinic and modern approaches are fundamentally opposed on matters of textual polyvalence/ monovalence. Here I think his contrast might be serviceable if we expand his specific discussion of rabbinic interpretation to the more general premodern theological inquiry into Scripture carried out by both Jews and Christians.

${ }^{20}$ For a recent full discussion of textual criticism and its developments in light of the Qumran scrolls, see Eugene C. Ulrich, "Our Sharper Focus on the Bible and 
tural text during the biblical period contained signs of textual pluriformity. This suggests that in the ancient world, Scripture's authority did not reside in fixed texts - ones that can be traced to the earliest human authors-but rather in a more transcendent understanding of the text.

The Dead Sea Scrolls provide textual evidence of a time period that was critically important for not only Christianity but also later forms of normative Judaism. Over 900 manuscripts have been identified and grouped from the caves at Qumran with a large number of the texts falling in the category of "biblical" texts. These texts that aligned with what later became known as canonical texts. During the time of Qumran, these writings exhibit a broad range of pluriformity. Somewhat ironically, during what we term the biblical period, there was no Bible as we know it, only a notion of scriptural texts that were authoritative for particular communities. A major consequence of the discovery of the Dead Sea Scrolls has been the challenge of the methodological assumptions of the historical-critical method that privilege one literal text and prioritize its earliest recoverable form. In particular, the textual-critical method, understood to be the disciplined recovery of the original form of the text, has been able to demonstrate the futility of historical criticism's presupposition of linear development by underscoring the radical pluriformity of the scriptural text in the Second Temple period.

The new manuscript evidence of the Dead Sea Scrolls suggests that not only were the Scriptures radically pluriform, but that during the Second Temple period, there was no ideological association with a particular textual version. ${ }^{21}$ This ancient attitude toward the Scriptures could perhaps

Theology Thanks to the Dead Sea Scrolls," Catholic Biblical Quarterly 66 (2004) $1-24$.

${ }^{21}$ Eugene C. Ulrich, "The Community of Israel and the Composition of the Scriptures," repr. in The Dead Sea Scrolls and the Origins of the Bible (Grand Rapids: Eerdmans, 1999) 15-16. A similar discussion on the ideological ties of the Peshitta OT to Judaism or to Syriac Christianity is also found in the literature; see the representative works by Sebastian P. Brock, "The Peshitta Old Testament: Between Judaism and Christianity," Cristianesimo nella storia 19 (1998) 483-502, and "Jewish Traditions in Syriac Sources," Studies in Syriac Christianity: History, Literature and Theology (Hampshire Great Britain: Variorum, 1992) 212-32; Jan Joosten, "La Peshitta de l'Ancien Testament dans la recherché récente," Revue d'histoire et de philosophie religieuses 76 (1996) 389; Peter B. Dirksen, "The Old Testament Peshitta," Mikra 261-97; Yeshayahu Maori, "The Peshitta Version of the Pentateuch in its Relation to the Sources of Jewish Exegesis" (Ph.D. diss., Hebrew University of Jerusalem, 1975); Perets ben Barukh Asher Perles, Meletemata Peschitthoniana (Bratislav: W. Friedrich, 1859). The great abundance of Jewish exegetical material, among other reasons, contributes to the overwhelming position confirming the traditional claim that the Peshitta was a Jewish translation. 
help us understand why the rabbis, given their meticulous attention to the written word, never developed a scientific textual criticism (as moderns would recognize it). ${ }^{22}$ Bruce Metzger remarks in his work on the New Testament canon that "Eusebius and Jerome, well aware of such variation in the witnesses, discussed which form of text was to be preferred. It is noteworthy, however, that neither Father suggested that one form was canonical and the other was not."23

Among the texts discovered at Qumran was a group of writings that scholars refer to as pesharim for their formulaic use of the word pishrô 'al, "its interpretation concerns." Characterized by its eschatologicallyoriented contemporizing exegesis, this form of interpretation appears to have been applied only to prophetic writings. ${ }^{24}$ Shani Berrin's recent article on these texts notes that the Qumran pesharim, in common with later rabbinic petira, includes an awareness of the polyvalence of the biblical text. ${ }^{25}$ According to Berrin, both the pesharim and the rabbinic petira assume that Scripture possesses both the literal (nigleh) and nonliteral (nistar) meanings. The former is less significant than the latter, which is the esoteric meaning revealed through the inspired interpretation of the exegete. Timothy Lim's studies on the pesharim suggest that even though this literary genre makes a clear distinction between the quoted scriptural lemma and its interpretation, the Qumran interpreter felt free to make small textual changes in the quoted lemma in order to make a stronger connection to the revealed esoteric interpretation. ${ }^{26} \mathrm{~A}$ similar attitude to-

${ }^{22}$ Philip S. Alexander, "Why No Textual Criticism in Rabbinic Midrash? Reflections on the Textual Culture of the Rabbis," Jewish Ways of Reading the Bible, ed. George J. Brooke (Oxford: Oxford University on behalf of the University of Manchester, 2000) 175-90.

${ }^{23}$ Bruce Metzger, The Canon of the New Testament: Its Origin, Development, and Significance (Oxford: Clarendon, 1987) 269-70; also cited by Ulrich, "Qumran and the Canon of the Old Testament" 3.

24 Jean Carmignac originally classified the pesharim into two categories, the continuous and the thematic: "Le document de Qumrân sur Melkisédeq," Revue de Qumrân 7 (1969-1971) 360-61. This essay discusses only the continuous pesharim. Of that type, only pesharim on biblical prophetic texts, Habakkuk, Zephaniah, Isaiah, Micah, Hosea, Nahum, and Psalms, have survived (1QpHab, 1QpMic, 1QpZeph, 1QpPs, 4QpIsa ${ }^{\mathrm{a}}$, 4QpIsa ${ }^{\mathrm{b}}, 4 \mathrm{QpIsa}^{\mathrm{c}}, 4 \mathrm{QpIsa}^{\mathrm{d}}, 4 \mathrm{QpIsa}^{\mathrm{e}}, 4 \mathrm{QpHos}^{\mathrm{a}}$, 4QpHos ${ }^{\mathrm{b}}, 4 \mathrm{QpNah}, 4 \mathrm{QpZeph}, 4 \mathrm{QpPs}{ }^{\mathrm{a}}$, 4QpPs ${ }^{\mathrm{b}}$. See Maura P. Horgan, Pesharim: Qumran Interpretations of Biblical Books (Washington: Catholic Biblical Association of America, 1979); and S. Berrin. "Qumran Pesharim," Biblical Interpretation at Qumran, ed. M. Henze (Grand Rapids, Mich.: Eerdmans, 2005) 110-33.

${ }^{25}$ Berrin, "Qumran Pesharim" 132.

${ }^{26}$ Timothy H. Lim, Holy Scripture in the Qumran Commentaries and Pauline Letters (Oxford: Clarendon, 1997) 95-120. The pesharist also seems to have made small omissions of verses or possibly omitted entire chapters; e.g., Hab 3 is entirely missing from 1QpHab (Lim 93). 
ward the Scriptures was detected by George Brooke in his study of the scriptural citations found in the sectarian document, $4 \mathrm{QMMT}{ }^{27}$

The ancient understanding of the scriptural text allowed for both its textual pluriformity and its transcendent significance. Textual-critical studies on the Qumran Scrolls highlight this feature of the scriptural text in the Second Temple period and present to us a realization of the sacred text as pluriform and not fixed. This attitude toward the text is perhaps closer to the attitude toward the scriptural texts held by Antiochene exegetes like the Syriac fathers. ${ }^{28}$ Thus, the historical-critical presuppositions that privilege one form of a scriptural text runs contrary to the historical reality of the ancient world. Textual criticism, when applied with the evidence of the scrolls, reintroduces a premodern understanding of "Scripture" which holds that the authoritative status of a text ${ }^{29}$ does not rely on its specific textual form, but on a different conception of why that text was authoritative. ${ }^{30}$

It seems clear that the authority of the text in premodern communities came not from its fixed form but from the recognition of that text as a divinely inspired work whose divine authorship transcended the multiple human agents responsible for the production of multiple texts. ${ }^{31}$ In the case of the scriptural text, the community's recognition of the divine authorship

${ }^{27}$ Brooke writes, "Along with many other scrolls which contain explicit citation of scripture, it seems that MMT helps us to see that we should not look for nor expect to find scripture quoted exactly in the form it is known to us in the MT. Nor should citations which contain no major words other than those which are also to be found in the MT be discarded as non-biblical" ("The Explicit Presentation of Scripture in 4QMMT," Legal Texts and Legal Issues: Proceedings of the Second Meeting of the International Organization for Qumran Studies, Cambridge 1995: Published in Honour of Joseph M. Baumgarten, ed. Moshe Bernstein, Florentino García Martínez, and John Kampen [New York: Brill, 1997] 88).

${ }^{28}$ Anthony Gelston notes various examples of variants between the Peshitta and the Hebrew MT, and argues that the Peshitta text is a free translation that goes back to a Hebrew Vorlage (The Peshitta of the Twelve Prophets [New York: Oxford, 1987] 131-56). See also the discussion in Dirksen, "The Old Testament Peshitta" 259.

${ }^{29}$ We could refer to the text's authoritative status as its "canonical" status, but it would be anachronistic to apply such terminology to the Qumran texts.

${ }^{30}$ Ulrich, "Qumran and the Canon of the Old Testament" 57-80. He writes, "As the definitions of canon amply illustrate, discussions of canon focus on the book considered as a literary opus, not the textual form of the opus. It is the book that is canonical, and there is no attention paid to the particular wording or textual form of the opus" (59).

${ }^{31}$ Such a distinction was previously offered by Dominque Barthélemy who suggested that it would be helpful to distinguish between "literary and scriptural authenticity," in which the latter (scriptural authenticity) would allow for many forms of the text (Critique textuelle de l'Ancient Testament, I [Göttingen: Vandenhoeck \& Ruprecht, 1982] 103-14). Also note the discussion by Brock, "To Revise or Not to 
of the written text conferred authority on what had been written and transformed it from human writing to divine revelation, that is, Scripture. The divine author's role differed from the human writer's; the former gave the text its authority, the latter played a part in the actual production of the physical object.

Recognition of the scriptural text's transcendence as divine writing led to an understanding of the text that is closer to a premodern understanding. Textual criticism helps us recognize the great pluriformity of the text in the ancient period. This in turn leads to the conclusion of the necessary existence of a transcendent text and divine author. This view of the Scriptures is closer to a premodern understanding. There was no expectation among Jewish and Christian premodern interpreters that Scripture was a fixed text in the same way that classical models of textual criticism presumed it was. ${ }^{32}$ Religious communities in antiquity simply did not understand textual fixity to be a criterion for the authority of a text in the same way that modern interpretive strategies of textual criticism do.

In sum, textual criticism may contribute to a greater awareness of what ancient communities of faith understood to be Scripture. Moreover, the religious commitments of the community that transmitted the text are preserved in the various textual variants that arise naturally during the transmission process and testify to the actualization of the Scriptures for that community. Instead of the traditional model of a linear development that understood textual deviations to be the functional deficiencies of the scribe, in antiquity the translation and transmission of a text were understood to be an inspired and interpretive activity that began to take on its characteristic features during the postexilic period with the rise of scribalism and inspired exegesis. Prior to their canonization, these texts were not yet fixed, and the boundary between the text and its interpretation was more porous. The Scriptures that are known today were formed from the compounding of interpretations, similar to the interpretive expansions and accretions that are made to the preexilic prophecy of Isaiah during the exilic and the postexilic periods. Thus, the transmission and translation of Scripture is a process that is more than merely functional. Its transmission involves the interlacing of scribal interpretation into the text to some degree. ${ }^{33}$ At times, the scribe creatively contemporizes or actualizes the text

Revise: Attitudes to Jewish Biblical Translation," Septuagint, Scrolls and Cognate Writings: Papers Presented to the International Symposium on the Septuagint and Its Relations to the Dead Sea Scrolls and Other Writings (Manchester, 1990), ed. George J. Brooke and Barnabas Lindars (Atlanta: Scholars, 1992) 332-33.

${ }^{32}$ Alexander, "Why No Textual Criticism in Rabbinic Midrash?" 175-90.

${ }^{33}$ Fishbane, Biblical Interpretation in Ancient Israel; Kugel, "Early Interpretation." 
allowing these interpretive elements to become thoroughly mingled with the preexisting tradition as we see in the postexilic sage who gives an inspired interpretation of the sacred texts, ${ }^{34}$ or as we shall see in the creativity of the great Syrian poet Ephrem.

\section{A LOOK AT THE SYRIAC EXEGETICAL TRADITION}

Scholars often distinguish premodern interpretive traditions by their views toward the literal sense of Scripture: the Antiochene view, noted for taking seriously and even privileging the literal sense of Scripture, differed from the Alexandrian position in this regard, although those stark divides have been blurred somewhat by scholars of recent years. ${ }^{35}$ Also, the particular location of Syriac-speaking exegetes within the Antiochene school of interpretation is yet another scholarly conversation that continues to unfold. While some might even challenge the Antiochene characterization of the Syriac writings today, others claim that the distinctive exegetical tradition of the Antiochene interpreters is properly described as influenced by the Syriac-speaking world. ${ }^{36}$

The work of Ephrem (306-373) shows how the Syriac exegetical tradi-

${ }^{34}$ A classic example is Daniel who offers the revealed understanding of Jeremiah's 70 years prophecy in Dan 9:24; see Kugel's comments in Early Biblical Interpretation 58.

${ }^{35}$ See M. F. Wiles, "Theodore of Mopsuestia as Representative of the Antiochene School," in The Cambridge History of the Bible 489-510; David S. WallaceHadrill, Christian Antioch: A Study of Early Christian Thought in the East (New York: Cambridge University, 1982) 27-51; Sten Hidal, "Exegesis of the Old Testament in the Antiochene School with its Prevalent Literal and Historical Method," in Hebrew Bible/Old Testament 543-68; van Rompay, "Antiochene Biblical Interpretation: Greek and Syriac," in The Book of Genesis in Jewish and Oriental Christian Interpretation 103-23; R. B. ter Haar Romeny, "Eusebius of Emesa's Commentary on Genesis and the Origins of the Antiochene School," in ibid. 125-42; John J. O'Keefe, “'A Letter that Killeth': Toward a Reassessment of Antiochene Exegesis, or Diodore, Theodore, and Theodoret on the Psalms," Journal of Early Christian Studies 8 (2000) 83-104; Frances Young, "Alexandrian and Antiochene Exegesis," A History of Biblical Interpretation, vol. 1: The Ancient Period, ed. Alan J. Hauser and Duane F. Watson (Grand Rapids, Mich.: Eerdmans, 2003) 334-54.

${ }^{36}$ For the latter, see particularly van Rompay, "Quelques remarques sur la tradition syriaque de l'oeuvre exégétique de Théodore de Mopsueste," IV Symposium Syriacum 1984: Literary Genres in Syriac Literature, ed. Hans J. W. Drijvers et al. (Rome: Pontifical Oriental Institute, 1987) 33-43; van Rompay, "Antiochene Biblical Interpretation: Greek and Syriac," 103-23; ter Haar Romeny, "Eusebius of Emesa's Commentary on Genesis" 125-42; also Leloir, "Symbolisme et parallélisme chez Saint Ephrem," À la rencontre de Dieu: Mémorial Albert Gelin (Paris: X. Mappus, 1961) 363-74; all of whom favor including the Syrian fathers with the Antiochenes, contra Pierre Yousif who holds that Ephrem, because he is prior to Diodore (the long-recognized founder of the Antiochene school, ca. 392), is not 
tion in antiquity offered rich examples of theological attitudes toward the scriptural text. His mastery as a poet and exegete gave rise to various ancient legends about his miraculous inspiration. ${ }^{37}$ The great Syriacist, Robert Murray, remarked that "Ephrem is emphatically no fundamentalist in his understanding of the Bible." 38 Such an assessment is drawn from Ephrem's own statements about Scripture, as can be seen in the following reference from his commentary on the Diatessaron VII, 22:

If there were [only] one meaning for the words [of Scripture] the first interpreter would find it, and all other listeners would have neither the toil of seeking nor the pleasure of finding. But every word of our Lord has its own image, and each image has many members, and each member possesses its own species and form. Each person hears in accordance with his capacity, and it is interpreted in accordance with what has been given him. ${ }^{39}$

Of all Ephrem's writings, however, his verse homilies (mêmrâ) and doctrinal hymns (madrašâ) best illustrate his artistic skill and theological attitude toward Scripture. These types of writings, unlike his biblical commentaries or other antiheretical writings which may have been used in a school setting, were compositions intended for a community of faith. Like many Christian interpreters from both the East and the West, Ephrem looked at Scripture through a christological lens.

The christological significance of the Old Testament Scriptures is not found in a surface reading of the text alone, but is often discerned by words

properly of the Antiochene School ("Exegetical Principles of Ephraem," Studia Patristica 18 [1990] 298).

In a later study on Eusebius of Emesa, ter Haar Romeny notes too that evidence suggesting influence from Syriac traditions on the Antiochene school may be seen not only in the geographic location of Antioch and its role as the capitol of the Province of Syria but also in the tradition that "the school of Antioch was founded by the Syrian martyr Lucian (d. 312)" ("Eusebius of Emesa and the Antiochene School" 129). Eusebius of Emesa was also of Eastern origins, having been born in Edessa.

${ }^{37}$ According to Byzantine Syriac vita tradition. Ephrem received a supernatural gift of eloquence and wisdom: "The day after he received the document he became filled with the Holy Spirit, and began uttering marvelous things, going about preaching and teaching many. In the morning, he heard the hermits saying: 'Look, Ephrem is teaching as though a fountain were flowing from his mouth.' Then the old man realized that what was coming from his lips was from the Holy Spirit" (see manuscript BL 9384, trans. Joseph Phillip Amar in his "The Syriac Vita Tradition of Ephrem the Syrian" [Ph.D. diss., Catholic University of America, 1988] 234-35).

${ }^{38}$ Robert Murray, "The Theory of Symbolism in St. Ephrem's Theology," Parole de l'Orient 6/7 (1975/1976) 6.

${ }^{39}$ Syrus Ephraem, Saint Ephrem's Commentary on Tatian's Diatessaron: An English Translation of Chester Beatty Syriac MS 709 with Introduction and Notes by Carmel McCarthy (Oxford: Oxford University for the University of Manchester, 1993) 139. 
or phrases that point toward deeper symbolic meanings. Scripture is used to illuminate Scripture, linking one text with another by a common word or motif. Typological readings were not only anchored by verbal signifiers but also by analogous events or characters. Ephrem's exegetical approaches are often characterized as resisting allegory while attributing considerable importance to the literal or historical meaning of the text and typology. ${ }^{40}$ We see that in addition to influence from the various traditions of Syriac asceticism, ${ }^{41}$ Ephrem's work shows knowledge of interpretative strategies familiar to Jewish sages. ${ }^{42}$ Sidney Griffith remarks that Ephrem's connection with Jewish strategies of interpretation "reminds the modern reader of Ephraem's work that in the Christian world of the Semitic languages there was a certain continuity of thought and imagination with the Jewish world about the interpretation of the biblical narratives that one does not always find in Greek and Latin commentaries." ${ }^{43}$ Some have wanted to locate Jewish influence on the interpretive writings of Ephrem in his knowledge

${ }^{40}$ The typological approaches of the premodern world are conflated at times with allegorical approaches. During some periods, the terms typology and allegory are interchangeable. See Henri de Lubac, "Typology and Allegorization," Theological Fragments, trans. Rebecca Howell Balinski (San Francisco: Ignatius, 1989) 129; first published in Recherches de science religieuse 35 (1947) 180-226. The typological approach toward Scripture, otherwise described as Ephrem's use of "universal symbolism," is identified by Bertrand de Margerie as one of three of Ephrem's primary exegetical approaches. See Bertrand de Margerie, "La poésie biblique de Saint Ephrem exegete Syrien (306-373)," Introduction à l'histoire de l'exégèse, vol. 1, Les pères grecs et orientaux (Paris: Cerf, 1980) 177-79; see also Murray, "The Theory of Symbolism in St. Ephrem's Theology" 3.

${ }^{41}$ Brock notes Ephrem's triple heritage: influence from Mesopotamian traditions, Jewish traditions, and also, but in a more restrictive sense, Hellenistic traditions. See Sebastian P. Brock, "Jewish Traditions in Syriac Sources," Journal of Jewish Studies 30 (1979) 212, and The Luminous Eye: The Spiritual World of St. Ephrem, 2nd ed. (Kalamazoo: Cistercian, 1992) 19-21.

${ }^{42}$ See D. Gerson, "Die Commentarien des Ephraem Syrus im Verhältniss zur jüdischen Exegese: Ein Beitrag zur Geschichte der Exegese," Monatschrift für Geschichte und Wissenschaft des Judentums 17 (1868) 15-33, 64-72, 98-109, 141-49; Jefim Schirmann, "Hebrew Liturgical Poetry and Christian Hymnology," Jewish Quarterly Review, n.s. 44 (1953-1954) 123-61; Ignacio Ortiz de Urbina, Patrologia Syriaca (Rome: Pontifical Oriental Institute, 1965) 61; Nicolas Séd, "Les hymns sur le paradis de Saint Ephrem et les traditions juives," Le Muséon 81 (1968) 455-501; Tryggve Kronhom, Motifs from Genesis 1-11 in the Genuine Hymns of Ephrem the Syrian, with Particular Reference to the Influence of Jewish Exegetical Tradition (Uppsala: Almqvist \& Wiksell, 1978) 25-27.

${ }^{43}$ Sidney H. Griffith, 'Faith Adoring the Mystery': Reading the Bible with St. Ephraem the Syrian, The Père Marquette Lecture in Theology 1997 (Milwaukee: Marquette University, 1997) 15. Griffith notes: "It is not only the fact that the Syriac versions he and his continuators and imitators used have the Hebrew Bible rather than the Septuagint behind them, but that many aspects of the interpretation have their closest analogues in the Jewish exegetical tradition rather than in other 
or use of Targumic traditions, but it is impossible to isolate one channel of influence. $^{44}$

Noteworthy for this study is the sensitivity this Syriac interpreter has for the Scriptural text and its polyvalence. ${ }^{45}$ Ephrem is comfortable with the elusiveness and ambiguity of Scripture and also aware of the apparent inconsistencies found in its littera. Paul Russell, in his discussion of this aspect of Ephrem's exegesis, points to the following passage from Ephrem's Sermons On Faith (2.171-88):

Waves hurl him to waves, when he listens to the Holy Scriptures.

While seeking to hear "He is weary," you hear: "He is not tired."

One ear hears that "He sleeps," and the other: "He does not sleep."

One ear hears that "He is little and limited," the other also hears: "He fills the heavens." One ear hears that He has limbs, and that it is not too little to sense them. while thinking about the composition of Him, Who has no composition for it to perceive. While hearing that $\mathrm{He}$ is in one place, hear that $\mathrm{He}$ is in every place. While seeking to call Him "good," He is called "righteous." 46

Scripture's inconcinnities, well noted by source critics, were not dismissed but rather comfortably accepted by Ephrem. At the same time, he was attentive both to Scripture's littera and transcendent meaning as a revelatory discourse about Christ. His inspired exegesis was a way of revealing what was otherwise concealed in the Scriptures. It is this generous understanding of the polyvalence of the Scriptures that allows for both his theologically rich exegesis and his typological interpretations notable for their creativity and theological insight. ${ }^{47}$ Sebastian Brock writes about Ephrem's understanding of the text:

For Ephrem, both Scripture and Creation are replete with God's symbols and mysteries, symbols which may point vertically, as it were to his trinitarian Being, or horizontally to his incarnate Son.... In the Scriptures, however, God does not only reveal something of himself by means of symbols, he also clothes himself in human language, 'He puts on names', as Ephrem frequently expresses it. For the most part the names that God 'puts on' are only metaphors, borrowed from the human condition. Ephrem sees this as an act of immense condescension on the part of God,

Christian traditions" ('Faith Adoring the Mystery' 15). See also van Rompay's brief discussion of the overlapping concerns found in Syriac writings and some notable works from the Second Temple period: "The Christian Syriac Tradition of Interpretation," in Hebrew Bible/Old Testament 616-17.

${ }^{44}$ Gunter Stemberger, "Exegetical Contacts between Christians and Jews in the Roman Empire," Hebrew Bible/Old Testament 583-85.

${ }^{45}$ See van Rompay, "The Christian Syriac Tradition of Interpretation" 614-15. The expression, "textual plurality" is borrowed from Marguerite Harl, "La Septante et la pluralité textuelle des Écritures," La langue de Japet: Quinze études sur la Septante et le grec des chrétiens (Paris: Cerf, 1992) 253-66.

${ }^{46}$ Paul S. Russell, "Making Sense of Scripture: An Early Attempt by St. Ephraem the Syrian," Communio 28 (2001) 171-201, at 182-83.

${ }^{47}$ Ibid. 179. 
who comes down to meet humanity on its own terms, in its own language; he is insistent that we, for our part, should not abuse this graciousness by supposing that these 'names' or metaphors are to be understood literally. ${ }^{48}$

There is always something that remains undisclosed or elusive in Scripture, allowing for the vitality of future interpretations and inviting the exegete to continue scrutinizing and probing the revelatory text. ${ }^{49}$ The elusiveness of the written form of revelation is also illustrated by the theophanic passages that struggle to convey in words the human experience of the divine. Ezekiel's famous description of God-"like the bow in the cloud on a rainy day, such is the appearance of the surrounding splendor, it was the appearance of the likeness of the glory of the Lord, and I saw it and fell upon my face, and heard a voice speaking" (Ezek 1:28)-illustrates how the experience of the divine surpasses human words-each circumlocution failing to describe completely and conclusively the experience of God. These spiritual realities are both hidden and revealed through the mysteries (sometimes translated as "symbols") of both nature and Scripture. Ephrem described Scripture's revelatory power in the sixth and seventh stanzas of his eleventh hymn on paradise:

If someone concentrates his attention solely on the metaphors used of God's majesty, he abuses and misrepresents that majesty, and thus errs by means of those metaphors with which God had clothed Himself for his benefit, and he is ungrateful to that Grace which stooped low to the level of his childishness: although it has nothing in common with him, yet Grace clothed itself in his likeness in order to bring him to the likeness of itself.

Do not let your intellect be disturbed by mere names, for Paradise has simply clothed itself in terms that are akin to you;

${ }^{48}$ Brock, Luminous Eye 42.

${ }^{49}$ Brock writes, "When using these terms 'hidden' and 'revealed' Ephrem will be employing one of two totally different perspectives. Most frequently he will employ what we may term the human perspective: God is hidden, except in so far as he allows himself to be revealed. This human experience of God's hiddenness (kasyuta) is only possible through God's various instances of self-revelation. For a created being experience of all these different individual self-manifestations of God will never add up to a full revelation of God's hiddenness; the revelation is always partial. This means that this human perspective is essentially subjective: each individual will approach God's hiddenness by way of a different set of galyata, or points of revelation," Luminous Eye 27. 


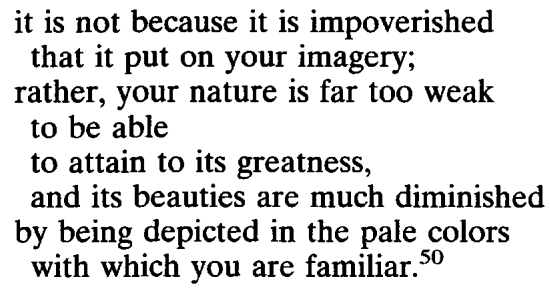

The literal or plain sense of the text does not dictate the meaning of the deeper spiritual realities that emerge when Ephrem weaves his tapestry of biblical allusions. As is typical in his writings, Ephrem describes the concealment and revelation of these spiritual realities through the mystery of the Incarnation, which is represented in these verses as putting on clothing.

Not only are the Scriptures polyvalent; the littera themselves are pluriform. Many scholars have sought to identify the precise biblical text Ephrem used in his theological works-wondering whether he cited a paraphrase of the biblical text or a Targumic version. This obscurity of source is also apparent in the writings of the Persian sage Aphrahat. Craig E. Morrison's recent study of the reception of the Book of Daniel in Aphrahat's Demonstrations highlights the textual plurality of that exegete. ${ }^{51}$ Morrison writes, "When citing the Bible, Aphrahat can adapt the citation to the argument he intends to develop. These adjustments to the biblical text do not witness to a memory lapse, but rather to his genius."52

As heirs to a similar tradition of interpretive strategies also manifest in the rabbis, these two great Syrian exegetes, Ephrem and Aphrahat, witness to a tradition of richly theological scriptural interpretation that succeeded in taking seriously the littera while avoiding the dangers of literalism. Both exegetes are remarkable for their literary artistry, and perhaps this aspect of their interpretive discourse contributes to the theological character of

${ }^{50}$ Syrus Ephraem, Hymns on Paradise, trans. and intro. Sebastian P. Brock (Crestwood, N.Y.: St. Vladimir's Seminary, 1998) 48-49.

${ }^{51}$ Craig E. Morrison, "The Reception of the Book of Daniel in Aphrahat's Fifth Demonstration, 'On Wars"' Hugoye 7 (2004). See also the comments on Syrian textual plurality by Moshe H. Goshen-Gottstein that early Syriac exegetes "often quoted from memory, omitted parts of verses, and of course, changed verses to fit their homiletic needs": "Prolegomena to a Critical Edition of the Peshitta," Text and Language in Bible and Qumran (Jerusalem-Tel Aviv: Orient, 1960) 197. Note also Robert Owens's comment that Aphrahat relied on his memory: "the looseness of so many of the citations suggests indeed a general pattern of memoriter rather than transcriptional quotation" (Robert J. Owens, The Genesis and Exodus Citations of Aphrahat, the Persian Sage [Leiden: Brill, 1983] 247).

${ }^{52}$ Morrison, "The Reception of the Book of Daniel" no. 31. Morrison concludes that the textual variants do not result from a failed memory but rather a different textual version of the Peshitta. 
their writings which speak about the divine rather than try to define it. ${ }^{53}$ It should also be remembered that classical Jewish exegesis exhibited great diversity. It was not exclusively literal but was a richly theological tradition. ${ }^{54}$

\section{CONCLUDING ASSESSMENT}

Scripture, given its divine quality, transcends the many variations of the literal text itself. Premodern faith communities of interpreters, both Jewish and Christian, conceptualized Scripture in a way that recognized its revelatory significance, while taking seriously its wording or textuality. In other words, ancient interpreters paid careful attention to the littera while avoiding the dangers of literalism. Textual criticism of the biblical texts of the Dead Sea Scrolls and the study of Syriac exegetical tradition can help us better understand ancient attitudes toward Scripture and also why scriptural interpretation-what McCarthy calls "embodied exegesis"-was more richly theological in the premodern period than in the modern period. A scientific perspective can impede theological inquiry because it conceptualizes Scripture as an object, but a historical perspective can illuminate the dynamic qualities and textual pluriformity that characterized Scripture and its interpretations for actual ancient communities defined by faith commitments. A conceptualization of Scripture more attuned to premodern perspectives and more open to theological inquiry may recognize that textual pluriformity, polyvalence, and "embodied exegesis" can yield a discourse that seeks to reveal and not define the divine for communities of faith.

${ }^{53}$ See the discussion by Susan Ashbrook Harvey, "The Odes of Solomon," in Searching the Scriptures, 2 vols., ed. Elisabeth Schüssler Fiorenza, vol. 2, A Feminist Commentary (New York: Crossroad, 1994) 95.

${ }^{54}$ Stemberger, "Exegetical Contacts between Christians and Jews" 584; also Burton L. Visotzky, "Jots and Tittles: On Scriptural Interpretation in Rabbinic and Patristic Literatures," Prooftexts 8 (1988) 262. 